\title{
Effect of particle size on rate and extent of degradation of alfalfa hay, barley straw and ammonia-treated barley straw
}

\author{
U San Vicente, A de Vega, C Castrillo, JA Guada \\ Departamento de Producción Animal y Ciencia de los Alimentos, Universidad de Zaragoza, \\ Miguel Servet, 177, 50013 Zaragoza, Spain
}

Nutritive value of feedstuffs for ruminants depends on both their rate and extent of ruminal degradation, and passage through the rumen. Particle size is well known to affect degradation characteristics of forages (Bowman and Firkins, 1993, J Anim Sci, 71, 1623-1633) but most of the experiments performed up to date have associated grinding sieve opening to particle size, without taking into account the particle size distribution of the ground material. Moreover, fragility of forages may influence bacterial attachment and hence rate and extent of ruminal degradation (Mir et al, 1990, Anim Feed Sci Technol, 31, 17-27).

In the present experiment alfalfa hay ( $A$, $57.4 \%$ DOM), barley straw (S, $40.2 \%$ DOM) and ammonia-treated barley straw (TS, $51.1 \%$ DOM) were ground through a $3 \mathrm{~mm}$ screen and then wet sieved to obtain different particle sizes (1.2-3.0, 0.6-1.2, 0.3-0.6, 0.15-0.3 and 0.045$0.15 \mathrm{~mm}$ ). All fractions, including the unsieved samples, were incubated for up to $96 \mathrm{~h}$ in the rumen of three adult Rasa Aragonesa ewes $(43.0 \pm 0.51 \mathrm{~kg}$ average liveweight) fed $A, S$ and TS following a latin square design. Particles from each forage were only incubated in animals consuming the same diet. Dry matter degradation values at each incubation time were fitted to the models of either Ørskov and MacDonald (1979, J Agric Sci, Camb, 92,
499-503) or Dhanoa et al (1995, Br J Nutr, 73, 3-15), depending on the existence of a significative lag time. Protein degradation characteristics were also studied for alfalfa hay.

Average dry matter (DM) intakes were 74.5 , 29.2 and $45.9 \mathrm{~g} / \mathrm{kg} \mathrm{LW} 0.75$ for $A, S$ and TS, respectively. Forage type affected both rate $\left(0.066^{\mathrm{a}}, 0.026^{\mathrm{b}}\right.$ and $0.036^{\mathrm{b}} / \mathrm{h}$ for $\mathrm{A}, \mathrm{S}$ and $\mathrm{TS}$, respectively) and extent (64.4a, 63.5 and $71.6 \mathrm{~b} \%$ ) of DM degradation as did particle size (Table). There were no interactions forage type $x$ particle size. Values of DM extent of degradation for unsieved samples were intermediate to those for the different particle sizes, whereas rate of degradation was equal to that for the smallest size. When nitrogen degradation parameters of alfalfa hay were analyzed extent of degradation of unsieved samples were not different from those for the smallest sizes whereas rates of degradation were higher than those for any of the sieved fractions, and hence are supposed to be mainly influenced by the degradation characteristics of particles smaller than $0.045 \mathrm{~mm}$.

In conclusion, when using nylon bags to assess the nutritive value of forages, DM and $N$ degradation rates are mainly influenced by the behaviour of the smallest particle sizes, which may have implications on the estimation of diet characteristics for ruminants.

\begin{tabular}{llcc} 
Particle size & & $1.2-3.0$ & $0.6-1.2$ \\
\hline Dry matter & $\mathrm{a}+\mathrm{b}(\%)$ & $51.8^{\mathrm{d}}$ & $57.7^{\circ}$ \\
& $\mathrm{c}(/ \mathrm{h})$ & $0.038^{\mathrm{b}}$ & $0.043^{\mathrm{a}}$ \\
Alfalfa & $\mathrm{a}+\mathrm{b}(\%)$ & $58.0^{\mathrm{d}}$ & $64.9^{\mathrm{c}}$ \\
nitrogen & $\mathrm{c}(/ \mathrm{h})$ & $0.092^{\mathrm{b}}$ & $0.104^{\mathrm{b}}$
\end{tabular}

$\begin{array}{cccc}0.3-0.6 & 0.15-0.3 & 0.045-0.15 & \text { Unsieved } \\ 71.3^{b} & 77.5^{a} & 76.3^{a b} & 64.3^{c} \\ 0.036^{b} & 0.038^{b} & 0.051^{a} & 0.051^{a} \\ 78.9^{b} & 84.6^{a} & 86.5^{a} & 85.2^{a} \\ 0.108^{b} & 0.057^{c} & 0.103^{b} & 0.151^{a}\end{array}$

